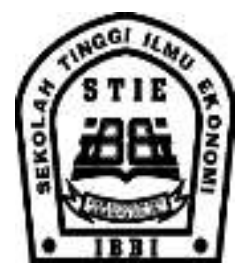

ISSN 1858-3199

JURNAL

MANAJEMEN BISNIS

STIE IBBI

\title{
PENGARUH IKLIM ORGANISASI DAN PENGEMBANGAN KARIR TERHADAP KEPUASAN KERJA PADA PT BANK INTERNASIONAL INDONESIA, TBK MEDAN
}

\author{
Juliani ${ }^{1}$ Hasrul Siregar ${ }^{2}$ \\ Manajemen STIE IBBI \\ juliani_dea75@yahoo.com
}

\begin{abstract}
Abstrak / Abstract
Tujuan penelitian ini adalah untuk menganalisis pengaruh iklim organisasi dan pengembangan karir terhadap kepuasan kerja pada PT Bank Internasional Indonesia, Tbk Medan. Penelitian ini menggunakan analisis deskriptif kuantitatif. Alat uji penelitian ini menggunakan model regresi linier berganda. Kesimpulan yang dapat diambil dari hasil pengujian, yaitu seluruh variabel independen berpengaruh terhadap kepuasan kerja. Sedangkan secara parsial iklim organisasi lebih dominan mempengaruhi kepuasan kerja, dibandingkan dengan pengembangan karir.
\end{abstract}

Kata Kunci : Iklim Organisasi, Pengembangan Karir dan Kepuasan Kerja 


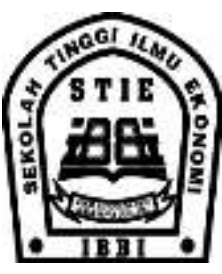

\section{PENDAHULUAN}

Pengelolaan sumber daya manusia yang tidak efektif dan efisien akan menghambat pencapaian tujuan perusahaan, dimana sumber daya manusia merupakan fungsi yang sangat penting dalam mengelola suatu perusahaan ataupun suatu organisasi. Untuk meningkatkan kinerja karyawan maka karyawan perlu merasa puas terhadap pekerjaan.

Kepuasan kerja merupakan wujud dari persepsi karyawan yang tercermin dalam sikap dan terfokus pada perilaku terhadap pekerjaan. Kepuasan kerja sebagai suatu sikap umum seseorang terhadap pekerjaannya. Kepuasan kerja merupakan salah satu elemen yang cukup penting dalam perusahaan. Hal ini disebabkan karena kepuasan kerja dapat mempengaruhi perilaku kerja. Kepuasan kerja itu sendiri dapat diartikan sebagai hasil kesimpulan yang didasarkan pada perbandingan mengenai apa yang secara nyata diterima oleh pegawai dari pekerjaannya dibandingkan dengan apa yang diharapkan, diinginkan dan dipikirkan sebagai hal yang pantas atau berhak baginya. Jika karyawan menerima hasil dari pekerjaannya sesuai dengan yang diharapkannya maka akan diperoleh kepuasan kerja. Kepuasan kerja yang terdapat dalam pekerjaan akan menggerakkan motivasi yang kuat sehingga dapat menghasilkan prestasi kerja yang baik. Ada beberapa komponen kepuasan kerja seperti kompensasi, pekerjaan, karir, lingkungan kerja dan faktor lainnya. Dan beberapa faktor yang dapat mempengaruhi kepuasan kerja tersebut adalah iklim organisasi dan pengembangan karir.

Penelitian ini dilakukan pada PT Bank Internasional Indonesia, Tbk yang bergerak di bidang usaha perbankan. Perusahaan membutuhkan karyawan yang mampu bekerja secara optimal. Oleh karena itu kepuasan kerja karyawan perlu ditingkatkan agar karyawan dapat bekerja secara maksimal. Apabila tingkat kepuasan kerja dalam suatu perusahaan rendah maka dapat menimbulkan gejala-gejala negatif yang akan terjadi dalam perusahaan seperti tingkat kehadiran yang rendah, malas bekerja, rendahnya prestasi kerja dan meningkatnya jumlah karyawan yang berhenti bekerja dan berpindah kerja pada perusahaan lain. Namun yang terjadi di perusahaan adalah tingkat kepuasan karyawan masih rendah. Kepuasan kerja yang berkaitan dengan tingkat pendapatan atau gaji kurang mencukupi dikarenakan banyaknya kebutuhan hidup karyawan. Dan selain itu kepuasan kerja juga tidak dapat dirasakan oleh karyawan karena tidak memiliki hubungan baik antara sesama karyawan sehingga mengurangi kepuasan kerja dari para karyawan itu sendiri. Para pegawai yang berprestasi tidak termotivasi karena kepuasan kerja yang didapat dari pekerjaan itu sendiri tidak terpenuhi, mereka berpikiran para pegawai yang berprestasi tidak memiliki kesempatan yang sama untuk menempati suatu jabatan. Pemimpin tidak melakukan supervisi dengan baik melalui pengarahan dan pembimbingan kepada karyawan agar dapat menyelesaikan pekerjaan dengan baik sehingga karyawan merasa tidak puas karena karyawan sering mengatasi permasalahan pekerjaan tanpa bantuan dari pemimpin. Beberapa karyawan juga merasa tidak puas karena pekerjaan yang diberikan tidak sesuai dengan kemampuan, latar belakang dan pengalaman yang dimiliki oleh karyawan sehingga banyak pekerjaan yang tidak dapat diselesaikan dengan cepat. Selain itu, perusahaan memberikan beban kerja yang banyak kepada karyawan sehingga karyawan merasa tidak puas dengan kondisi kerja yang ada pada perusahaan.

Kepuasan kerja karyawan di PT Bank Internasional Indonesia, Tbk mengalami penurunan dan sesuai pengamatan, hal tersebut terjadi oleh karena iklim organisasi kurang mendukung pekerjaan karyawan seperti sering terjadinya konflik yang menyebabkan terjadinya ketidakcocokan anatara rekan kerja sehingga konflik itu dapat mengganggu aktivitas bekerja dan akan membuat pegawai itu tidak dapat berkonsentrasi dalam bekerja. Kebijakan organisasi pun dinilai masih kurang efektif dikarenakan sebagian karyawan ditempatkan tidak sesuai dengan keahliannya sehingga menyebabkan para pegawai itu sulit 


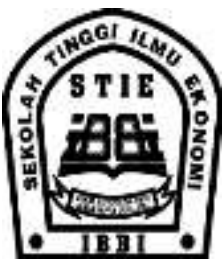

untuk memahami pekerjaan yang diberikan. Perusahaan juga tidak memberikan peran dan tanggung jawab yang sesuai dengan kemampuan karyawan. Perusahaan juga membatasi karyawan dalam berpartisipasi dalam kegiatan operasional perusahaan. Dukungan pemimpin dan rekan kerja masih kurang terhadap karyawan dengan membantu karyawan dalam kesulitan pekerjaan sehingga karyawan bekerja secara individual tanpa kerjasama dengan rekan kerja maupun masukan dari pimpinan.

Terdapat beberapa hal yang dapat terindikasi menjadi permasalahan dalam pengembangan karir karyawan pada perusahaan. Selama ini pengembangan karir karyawan masih kurang objektif dan transparan, dimana pimpinan cenderung mengedepankan suka atau tidak suka dalam mendukung karir karyawan bukan didasarkan pada kemampuan dari karyawan itu sendiri. Masalah pengembangan karir yang kurang objektif dan transparan tentunya dapat menghambat tujuan perusahaan untuk meningkatkan kepuasan kerja karyawan, sehingga dalam proses selanjutnya dapat menghambat optimalisasi pelayanan bagi pelanggan. Karyawan merasa sulit untuk naik ke level yang lebih tinggi. Selain itu program pelatihan dilakukan di luar perusahaan dan tidak semua karyawan dapat mengikuti dan memahami materi pendidikan dan pelatihan secara cepat mengingat latar belakang pendidikan yang tidak sama. Padahal keikutsertaan dalam program pendidikan dan pelatihan merupakan salah satu syarat bagi karyawan untuk meningkatkan karirnya. Di samping itu salah satu upaya yang dilakukan oleh perusahaan untuk pengembangan karir karyawan yaitu dengan rotasi kepada karyawan namun tidak semua karyawan dapat termotivasi dengan pelaksanaan rotasi tersebut hal ini disebabkan masih adanya karyawan yang tidak terbiasa dengan suasana, lingkungan atau wilayah kerja yang baru berdasarkan ketentuan dari pihak perusahaan sehingga dapat memungkinkan menurunnya kepuasan kerja dari karyawan itu sendiri.
Pengarahan dan bimbingan jarang dilakukan oleh pimpinan sehingga karyawan tidak mendapatkan masukan dan pengalaman yang lebih baik dalam melaksanakan pekerjaan secara lebih efisien dan efektif. Perencanaan karir pada perusahaan tidak dilakukan dengan baik melalui evaluasi dan pemantauan secara teratur dan berkelanjutan atas hasil kerja karyawan sehingga pengembangan karir dilakukan tanpa perencanaan yang akhirnya pengembangan karir dalam perusahaan tidak berjalan dengan baik dalam upaya meningkatkan kepuasan kerja karyawan.

Berdasarkan latar belakang, penulis tertarik untuk melakukan penelitian dengan judul "Pengaruh Iklim Organisasi dan Pengembangan Karir Terhadap Kepuasan Kerja pada PT Bank Internasional Indonesia, Tbk Medan"

\section{TINJAUAN LITERATUR Iklim Organisasi}

Menurut Thoha (2010:73), “iklim organisasi merupakan lingkungan internal yang mewakili faktor-faktor dalam organisasi yang menciptakan kultur dan lingkungan sosial dimana aktivitas-aktivitas pencapaian tujuan berlangsung". Iklim organisasi adalah persepsi anggota tentang lingkungan kerja organisasi Iklim organisasi menunjuk pada gaya material yang mempengaruhi pandangan anggota mengenai nilai dan tujuan organisasi. Iklim organisasi menunjuk pada karakteristik organisasi secara keseluruhan dan berhubungan dengan perasaan anggota yang bersangkutan.

Menurut Mondy (2010:163) ada empat prinsip faktor-faktor yang mempengaruhi iklim organisasi yaitu :
a. Manajer/pimpinan
b. Tingkah laku karyawan
c. Tingkah laku kelompok kerja
d. Faktor eksternal organisasi
Banyak hal yang berpengaruh di dalam organisasi sehingga terbentuklah iklim 


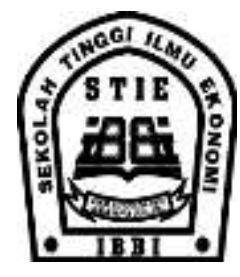

organisasi, hal tersebut menurut Mangkuprawira (2011:76) adalah :

1. Bekerja keras

2. Kerja sama

3. Peraturan

Menurut Griffin (2010:168) membagi

iklim organisasi dalam tiga pendekatan, yaitu:

a. Multiple measurement - organizational approach

b. Perseptual measurement organizational attribute approach

c. Perseptual measurement - individual approach

Menurut Robbins (2011:127), indikator iklim organisasi terdiri dari indikator sebagai berikut:

1. Struktur.

2. Standar-standar.

3. Tanggung jawab.

4. Pengakuan.

5. Dukungan.

6. Komitmen.

\section{Pengembangan Karir}

Sistem pengembangan karir bagi seorang pegawai merupakan hal penting dalam suatu organisasi. Keberhasilan organisasi dalam melaksanakan hal tersebut akan sangat bergantung pada partisipasi seluruh pegawai khususnya, kesungguhan dan juga konsistensi para pemimpinnya. Harus disadari bahwa pengembangan karir merupakan salah satu aktifitas yang sangat vital di dalam masalah kepegawaian.

Menurut Sunyoto (2011:183), "pengembangan karir adalah peningkatan pribadi yang dilakukan seseorang untuk mencapai suatu rencana karir dan peningkatan oleh departemen personalia untuk mencapai suatu rencana kerja sesuai dengan jalur atau jenjang organisasi”. Pengembangan karir yang menjadi keinginan setiap pegawai, semuanya berhubungan dengan upaya-upaya yang mendorong produktivitas mereka, sehingga mereka dapat memelihara kinerjanya dalam melakukan setiap aktivitas operasionalnya. Oleh karena itu, organisasi atau perusahaan perlu menyediakan kesempatan dan fasilitas
ISSN 1858-3199

JURNAL

MANAJEMEN BISNIS

STIE IBBI pengembangan karir. Disamping berguna untuk meningkatkan pengetahuan pegawai, juga dapat menghasilkan pegawai yang terampil.

Bentuk-bentuk pengembangan karir yang dilakukan oleh setiap perusahaan disesuaikan dengan jalur karir yang direncanakan, perkembangan, kebutuhan dan fungsi perusahaan itu sendiri. Bentuk pengembangan karir menurut Rivai (2010:291293), dapat dibagi menjadi empat yaitu :

1. Pengembangan karir pribadi

2. Pengembangan karir yang didukung departemen SDM

3. Peran pemimpin dalam, pengembangan karir

4. Peran umpan terhadap pengembangan karir

Pengembangan karir seorang pegawai sangat ditentukan oleh kinerjanya, meskipun di dalam promosi menduduki suatu posisi terentu ada yang mendasarkan pada siapa yang dikenal untuk memberikan umpan balik kepada pegawai tentang prestasi kerjanya, depatemen SDM mengembangkan prosedur pekerjaan secara formal. Hal ini akan memungkinkan pegawai tersebut untuk menyesuaikan prestasi kerjanya, kesempatan pengembangan karir serta kompensasi yang diberikan guna memenuhi kebutuhan perusahaan diwaktu mendatang dan juga keinginan para pegawainya.

Menurut Simamora (2010:416), bahwa ada tiga tahap dalam pengembangan karir, yaitu :

1. Karir awal

2. Karir pertengahan

3. Karir akhir

Menurut Nawawi (2010:307) indikator pengembangan karir adalah sebagai berikut :

1. Perencanaan karir

2. Pengarahan

3. Penyelenggaraan sistem bimbingan

4. Pelatihan

5. Rotasi jabatan 


\section{Kepuasan Kerja}

Kepuasan kerja pada dasarnya merupakan hal yang sifatnya individual, setiap individu akan memiliki tingkat kepuasan yang berbeda-beda dengan sistem nilai yang berlaku pada dirinya. Hal ini disebabkan karena adanya perbedaan masing-masing individu. Semakin banyak aspek-aspek dalam pekerjaan yang sesuai dengan keinginan individu tersebut, semakin tinggi kepuasan yang dirasakan, sebaliknya bila semakin sedikit aspek-aspek dalam pekerjaan yang sesuai dengan keinginan individu maka makin rendah tingkat kepiasannya. Menurut Handoko (2010:129), "kepuasan kerja adalah keadaan emosional yang menyenangkan atau tidak menyenangkan dengan mana para karyawan memandang pekerjaan".

Menurut Hariandja (2010:291) faktorfaktor yang mempengaruhi kepuasan kerja karyawan yaitu :

1. Gaji yaitu jumlah bayaran yang diterima seseorang sebagai akibat dari pelaksanaan kerja.

2. Pekerjaan itu sendiri yaitu isi pekerjaan yang dilakukan seseorang.

3. Rekan Sekerja yaitu teman-teman yang senantiasa berinteraksi dalam pelaksanaan pekerjaaan.

4. Promosi yaitu kemungkinan seseorang dapat berkembang melalui kenaikan jabatan.

5. Atasan yaitu seseorang yang senantiasa memberi perintah atau petunjuk dalam pelaksanaan kerja

Dalam penelitian oleh Robbins (2011:153) menyebutkan bahwa komponenkomponen yang menentukan kepuasan kerja adalah:

1. Kerja yang secara mental menantang akan membuat karyawan lebih menyukai pekerjaan yang dapat memberikan mereka kesempatan untuk menggunakan keterampilan dan kemampuan mereka serta menawarkan beragam tugas, kebebasan dan umpan balik.
2. Ganjaran yang pantas dalam hal ini yang dimaksud adalah karyawan menginginkan sistem upah dan kebijakan promosi yang mereka persepsikan sebagai adil dan sesuai dengan harapan mereka.

3. Kondisi kerja yang mendukung mempunyai arti karyawan yang peduli dengan lingkungan kerja, baik untuk kenyamanan pribadi maupun untuk memudahkan dalam melakukan pekerjaan yang baik.

4. Rekan kerja yang mendukung apabila karyawan mendapatkan lebih daripada sekedar uang atau prestasi dalam pekerjaannya. Bagi kebanyakan karyawan, kerja juga mengisi kebutuhan akan interaksi sosial.

5. Kesesuaian kepribadian dengan pekerjaan, Pada hakikatnya karyawan dengan tipe kepribadian kongruen (sama dan sebangun) dengan pekerjaan yang mereka pilih seharusnya akan menemukan bakat dan kemampuan yang tepat untuk memenuhi tuntutan dari pekerjaan mereka.

Menurut Istijanto, (2010:181), indikator kepuasan kerja yang dapat digunakan untuk mengukur kepuasan kerja karyawan:

a. Merasa tertarik kepada pekerjaannya.

b. Merasa nyaman bekerja.

c. Memiliki antusiasme tinggi.

d. Memiliki pengharapan untuk maju di perusahaan

e. Puas dengan kondisi perusahaan

\section{KERANGKA PEMIKIRAN}

Iklim organisasi sebagai kumpulan dan pola lingkungan yang menentukan munculnya motivasi serta berfokus pada suasana yang dirasakan karyawan, sehingga mempunyai pengaruh langsung terhadap kinerja karyawan. klim organisasi adalah lingkungan internal atau psikologi organisasi. Setiap perusahaan akan memiliki iklim organisasi yang berbeda. Keanekaragaman pekerjaan yang di dalam perusahaan atau sifat individu yang ada akan menyebabkan terjadinya perbedaan tersebut. 


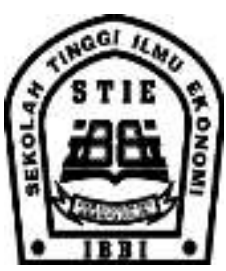

Iklim organisasi yang terbuka memacu karyawan untuk mengutarakan kepentingan dan ketidakpuasan tanpa adanya rasa takut akan tindakan balasan dan perhatian.

Pengembangan karir adalah aktivitas di perusahaan yang membantu karyawan merencanakan karir masa depan mereka di perusahaan agar karyawan dapat mengembangkan diri secara maksimal. Dalam praktek pengembangan karir lebih merupakan suatu pelaksanaan rencana karir yang merupakan proses peningkatan kemampuan kerja karyawan yang dilakukan dalam rangka mencapai suatu rencana karir yang diinginkan. Pengembangan karir dapat dikatakan suatu kondisi yang menunjukkan adanya peningkatan-peningkatan posisi karyawan dalam perusahaan dalam jalur karir pada perusahaan. Pengembangan karir adalah suatu pendekatan atau kegiatan yang tersusun secara formal untuk meningkatkan pengetahuan dan kemampuan karyawan agar perusahaan dapat memastikan bahwa orang-orang dengan kualifikasi dan pengalaman yang cocok tersedia dalam perusahaan. Tujuan dari pengembangan karir adalah untuk menyesuaikan antara kebutuhan dan tujuan karyawan dengan kesempatan karir yang tersedia di perusahaan saat ini dan di masa mendatang.

Kepuasan kerja adalah perasaan positif dan puas dengan kondisi pekerjaan di perusahaan. Kepuasan kerja juga berarti karyawan merasa senang dalam melakukan pekerjaan tanpa adanya rasa beban kerja yang berat. Kepuasan itu terjadi apabila kebutuhankebutuhan karyawan sudah terpenuhi di perusahaan. Tingkat kepuasan kerja berkaitan sikap yang terlihat pada karyawan yang erat kaitannya dengan imbalan-imbalan yang mereka terima setelah melakukan sebuah pekerjaan. Seorang dengan tingkat kepuasan kerja tinggi menunjukkan sikap positif terhadap kerja itu, sebaliknya seseorang tidak puas dengan pekerjaannya menunjukkan sikap negatif terhadap kerja itu. Semakin banyak aspek-aspek dalam pekerjaan yang sesuai dengan keinginan karyawan, maka akan semakin tinggi tingkat kepuasan yang dirasakan.

Iklim organisasi akan menciptakan suasana yang nyaman bagi karyawan sehingga karyawan menjadi betah untuk bekerja pada perusahaan serta memiliki semangat kerja yang tinggi. Pengembangan karir yang baik pada perusahaan akan memberikan manfaat bagi karyawan dalam mencapai karir yang diinginkan pada perusahaan. Dengan pengembangan karir maka kemampuan karyawan akan meningkat melalui pelatihan dan pengembangan sehingga karyawan akan merasa puas karena kesempatan karir pada perusahaan cukup jelas dan telah dipersiapkan dengan baik oleh perusahaan. Berdasarkan penjelasan di atas, iklim organisasi dan pengembangan karir berpengaruh terhadap kepuasan kerja karyawan. Adapun kerangka pemikiran dalam penelitian ini adalah:

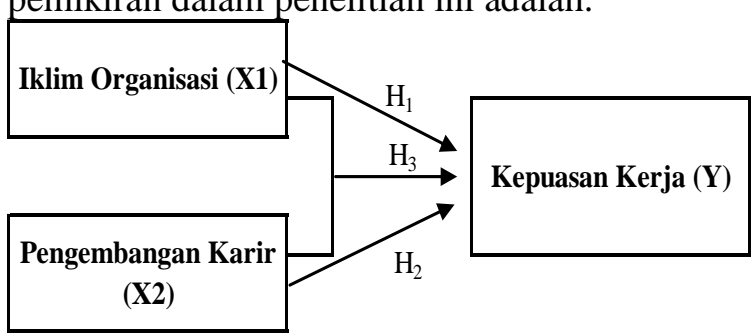

Gambar 1

Kerangka Pemikiran

\section{METODE PENELITIAN}

Penelitian ini dilaksanakan di PT Bank Internasional Indonesia, Tbk Medan. Waktu penelitian dimulai dari bulan Januari 2015 sampai dengan Juli 2015. Populasi yang akan diteliti adalah karyawan di PT. Bank Internasional Indonesia, Tbk Medan yang berjumlah 162 karyawan dan sampel penelitian juga sebanyak 62 orang dengan menggunakan rumus Slovin. Teknik analisa data yang digunakan adalah analisis regresi berganda setelah memenuhi asumsi klasik menyangkut normalitas, heteroskedastisitas dan multikolinearitas. Penarikan kesimpulan atas hipotesis dilakukan dengan cara uji $\mathrm{t}$ dan uji $\mathrm{F}$ pada level signifikansi 5\%. Keseluruhan tabulasi dan pengelolaan data menggunakan software SPSS versi 18. 


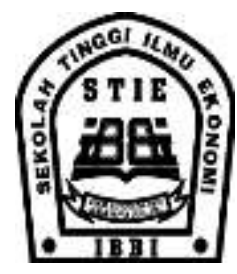

5. HASIL PENELITIAN

Hasil Analisis Regresi Berganda

Persamaan regresi berganda dalam penelitian adalah :

$$
\mathrm{Y}=1,799+0,464 \mathrm{X}_{1}+0,355 \mathrm{X}_{2}
$$

Pada persamaan regresi tersebut dapat dilihat bahwa iklim organisasi dan pengembangan karir mempunyai koefisien regresi positif yang membuktikan adanya kontribusinya terhadap kepuasan kerja pada PT Bank Internasional Indonesia, Tbk Medan. Hal ini menunjukkan bahwa kepuasan kerja pada PT Bank Internasional Indonesia, Tbk Medan dapat dipengaruhi oleh iklim organisasi dan pengembangan karir. Dengan kata lain pengaruh iklim organisasi dan pengembangan karir dapat meningkatkan kepuasan kerja pada PT Bank Internasional Indonesia, Tbk Medan.

\section{Hasil Uji t}

Uji t untuk menentukan signifikansi tidaknya (berarti atau tidaknya) suatu variabel penjelas atau variabel bebas dalam mempengaruhi variabel tidak bebas. Hasil penelitian menunjukkan bahwa :

a. Nilai $t_{\text {hitung }}$ iklim organisasi adalah 7,346 sedangkan $t_{\text {tabel }}=2,00$ berarti $t_{\text {hitung }}>t_{\text {tabel }}$ dan dengan tingkat signifikansi $0,000<$ 0,05 sehingga dapat disimpulkan bahwa variabel iklim organisasi berpengaruh positif dan signifikan terhadap kepuasan kerja.

b. Nilai $t_{\text {hitung }}$ pengembangan karir adalah 3,865 sedangkan $t_{\text {tabel }}$ bernilai 2,00 berarti $\mathrm{t}_{\text {hitung }}<\mathrm{t}_{\text {tabel }}$ dan dengan tingkat signifikansi $0,000<0,05$ sehingga dapat disimpulkan bahwa variabel pengembangan karir berpengaruh positif dan signifikan terhadap kepuasan kerja.

\section{Hasil Uji F}

Uji $F$ dilakukan dengan cara pengujian variabel-variabel bebas secara bersamaan. Tujuan dari pengujian variabel-variabel bersamaan adalah untuk menentukan apakah variabel-variabel bebas secara keseluruhan berpengaruh terhadap variabel terikat. Berdasarkan hasil uji F, hasil regresi menunjukkan signifikan $\mathrm{F}<$ alpha 5\% $(0,000<$ $0,05)$ yang berarti bahwa variabel iklim organisasi dan pengembangan karir secara simultan mempunyai pengaruh signifikan terhadap kepuasan kerja.

\section{Hasil Uji Koefisien Determinasi}

Koefisien determinasi ditujukan untuk mengetahui seberapa besar kemampuan model dalam menerangkan variabel terikat. Besarnya nilai koefisien determinasi sebesar 0,804 atau sama dengan $80,4 \%$. Artinya $80,4 \%$ kepuasan kerja dapat dijelaskan oleh variabel iklim organisasi dan pengembangan karir, sedangkan sisanya sebesar $19,6 \%$ dapat dijelaskan oleh faktor-faktor lain yang tidak dimasukkan dalam penelitian ini.

\section{PEMBAHASAN}

Berdasarkan uji statistik, iklim organisasi memiliki pengaruh terhadap kepuasan kerja pada PT Bank Internasional Indonesia, Tbk Medan. Perusahaan atau organisasi yang memiliki sumber daya manusia yang handal dapat menciptakan suatu iklim organisasi yang kondusif sehingga dapat meningkatkan motivasi pekerja dalam menyelesaikan pekerjaanya. Untuk itu, pengembangan karir harus di dukung pula dengan iklim organisasi yang baik sehingga menimbulkan motivasi kepada para pegawainya agar menyelesaikan tugas secara baik sehingga kepuasan kerja dapat diperoleh. Iklim organisasi adalah serangkaian deskripsi dari karakteristik organisasi yang membedakan sebuah organisasi dengan organisasi lainnya yang mengarah pada persepsi masing-masing anggota dalam memandang organisasi. Terdapat hubungan yang positif antara iklim organisasi dengan kepuasan kerja karyawan. Hasil penelitian ini sejalan dengan penelitian yang dilakukan oleh Anjar Wibowo (2012) dan Natassia Ayudiarini (2012) yang menyatakan iklim organisasi memiliki pengaruh terhadap kepuasan kerja.

Berdasarkan uji statistik, pengembangan karir memiliki pengaruh terhadap kepuasan 
kerja pada PT Bank Internasional Indonesia, Tbk Medan. Setiap karyawan harus mempunyai gambaran yang jelas tentang karir tertinggi apa yang bisa dicapainya selama dia menampilkan kinerja yang memuaskan. Pengembangan karir sebagai kegiatan manajemen Sumber Daya Manusia pada dasarnya bertujuan untuk memperbaiki dan meningkatkan efektivitas pelaksanaan pekerjaan oleh pekerjaan oleh para pekerja, agar semakin mampu memberikan kontribusi terbaik dalam mewujudkan tujuan bisnis organisasi. Pengembangan karir merupakan hal yang penting dimana manajemen dapat meningkatkan produktivitas, meningkatkan sikap karyawan terhadap pekerjaannya dan membangun kepuasan kerja yang lebih tinggi. Hasil penelitian ini sejalan dengan penelitian yang dilakukan oleh Audra Bianca (2012) dan Natassia Ayudiarini (2012) bahwa pengembangan karir memiliki pengaruh signifikan terhadap kepuasan kerja.

Penelitian ini menggunakan dua variabel independen dan kemungkinan masih ada variabel lain yang diduga berpengaruh terhadap kepuasan kerja. Sampel yang sedikit yaitu 62 sampel dan terbatas pada PT Bank Internasional Indonesia, Tbk Medan. Untuk periode pengamatan hendaknya melakukan penelitian dengan periode yang lebih lama. Sampel yang digunakan bisa lebih banyak lagi. Penelitian ini dapat diperluas dengan menambah variabel bebas lainnya yang diduga berpengaruh terhadap kepuasan kerja.

\section{KESIMPULAN DAN SARAN}

\section{Kesimpulan}

Dari hasil penelitian, dapat diambil kesimpulan sebagai berikut :

1. Secara parsial, variabel iklim organisasi memiliki pengaruh yang positif dan signifikan terhadap kepuasan kerja pada PT Bank Internasional Indonesia, Tbk Medan.

2. Secara parsial, variabel pengembangan karir memberikan pengaruh yang positif dan signifikan terhadap kepuasan kerja pada PT Bank Internasional Indonesia, Tbk Medan.

3. Secara simultan, variabel iklim organisasi dan pengembangan karir memiliki pengaruh positif dan signifikan terhadap kepuasan kerja pada PT Bank Internasional Indonesia, Tbk Medan.

4. Berdasarkan analisa korelasi determinasi (Adjusted $R$ Square), variabel iklim organisasi dan pengembangan karir berpengaruh dan dapat menjelaskan oleh variabel terhadap kepuasan kerja pada PT Bank Internasional Indonesia, Tbk Medan sebesar 80,4 \% dan sisanya sebesar 19,6\% dipengaruhi oleh faktor lain yang tidak dimasukkan dalam penelitian ini.

\section{Saran}

Beberapa saran dan rekomendasi dari penelitian ini antara lain:

1. Perusahaan perlu mempertahankan iklim organisasi yang sudah baik dan menyesuaikan dengan kondisi perusahaan serta kemampuan manajemen perusahaan diharapkan terus ditingkatkan sehingga mampu mencapai tujuan perusahaan jangka panjang yaitu dengan menerapkan kebijakan dan peraturan organisasi yang memudahkan karyawan dalam melaksanakan pekerjaan. Selain itu perusahaan perlu menetapkan prosedur kerja dan uraian pekerjaan yang jelas sehingga karyawan tidak mengalami kebingungan dalam melaksanakan pekerjaan dan dapat terjadi saling kerja sama antara karyawan. Perusahaan juga perlu menciptakan iklim organisasi yang saling bekerja sama dan menghormati untuk menjalin keakraban antara karyawan maupun dengan atasan. Dengan mempertahankan iklim organisasi yang baik maka perusahaan akan dapat menerapkan sistem manajemen yang baik dalam rangka meningkatkan kepuasan kerja. 


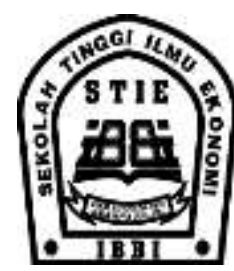

2. Untuk lebih meningkatkan pengembangan karir karyawan maka harus lebih meningkatkan hubungan kerja antara atasan dan bawahan, di samping itu perusahaan harus mampu menyesuaikan perencanaan karir individu dengan rencana karir yang ada di perusahaan. Di sisi lain, karyawan harus mampu memotivasi dirinya agar karirnya dapat berkembang, karena juga berpengaruh terhadap peningkatan penghasilan. Pimpinan perusahaan harus lebih sering memberikan motivasi kepada karyawan untuk bekerja lebih baik, menempatkan karyawan berdasarkan latar belakang pendidikan, minat dan kemampuan karyawan tersebut, melakukan promosi tidak hanya melihat masa kerjanya tetapi juga dari kinerja karyawan. Karena dengan memberikan dukungan kepada karyawan yang berpotensial serta menyediakan posisi sebagai sarana pengembangan karir karyawan akan mampu membuat karyawan menghasilkan kinerja sebaik mungkin.

\section{DAFTAR PUSTAKA}

Ayudiarini, Natassia. 2012. Pengaruh Iklim Organisasi dan Pengembangan Karir Terhadap Kepuasan Kerja pada Industri Jasa Asuransi Asuransi Ramayana. Jakarta : Universitas Gunadarma

Bianca, Audra. 2012. Pengaruh Iklim Organisasi dan Pengembangan Karir Terhadap Kepuasan Kerja Karyawan PT KHI Pipe Industries Cilegon. Banten : Universitas Sultan Ageng Tirtayasa

Griffin. 2013. Perilaku Organisasi: Manajemen Sumber Daya Manusia dan Organisasi. Jakarta : Penerbit Salemba Empat.
ISSN 1858-3199

JURNAL

MANAJEMEN BISNIS

STIE IBBI

Handoko, T. Hani. 2010. Manajemen Personalia dan Sumber Daya Manusia. Yogyakarta : Penerbit BPFE Yogyakarta.

Hariandja, Marihot Tua Efendi. 2010. Manajemen Sumber Daya Manusia. Jakarta: Penerbit Grasindo.

Istijanto. 2010. Riset Sumber Daya Manusia. Jakarta : PT. Gramedia Pustaka Utama

Mangkuprawira, Sjafri. 2011. Manajemen Sumber Daya Manusia Strategi. Jakarta : Penerbit Ghalia Indonesia.

Mondy, Wayne. 2010. Manajemen Sumber Daya Manusia. Jakarta : Penerbit Erlangga.

Nawawi, Hadari. 2010. Manajemen Sumber Daya Manusia. Yogyakarta : Gadjah Mada University Press.

Rivai, Veithzal. 2010. Kepemimpinan dan Perilaku Organisasi. Jakarta : Penerbit Rajawai Pers

Robbins, Stephen. 2011. Perilaku Organisasi. Jakarta : Penerbit Salemba Empat.

Simamora, Henry. 2010. Manajemen Sumber Daya Manusia. Yogyakarta : STIE YKPN Yogyakarta.

Sunyoto, Danang. 2011. Manajemen Sumber Daya Manusia. Jakarta : Caps Publishing.

Thoha, Miftah. 2010. Perilaku Organisasi : Konsep dan Aplikasinya. Jakarta : Penerbit Rajawai Pers.

Wibosono, Anjar. 2012. Pengaruh Iklim Organisasi Terhadap Kepuasan Kerja Pegawai Puskesmas Turen di Malang. Balikpapan : Universitas Balikpapan Kalimantan. 